Published in final edited form as:

Biol Psychiatry. 2012 September 1; 72(5): 347-353. doi:10.1016/j.biopsych.2012.02.016.

\title{
The role of ghrelin in reward-based eating
}

\author{
Mario Perelló, Ph.D. ${ }^{1}$ and Jeffrey M. Zigman, M.D., Ph.D. ${ }^{2,3}$ \\ ${ }^{1}$ Laboratory of Neurophysiology, Multidisciplinary Institute of Cell Biology (IMBICE-CONICET/ \\ CICPBA), Calle 526 s/n entre 10 y 11, La Plata, Buenos Aires, Argentina 1900 \\ 2Department of Internal Medicine (Divisions of Hypothalamic Research and of Endocrinology \& \\ Metabolism), The University of Texas Southwestern Medical Center, 5323 Harry Hines Blvd., \\ Dallas, Texas 75390-9077 \\ ${ }^{3}$ Department of Psychiatry, The University of Texas Southwestern Medical Center, 5323 Harry \\ Hines Blvd., Dallas, Texas 75390-9077
}

\begin{abstract}
The peptide hormone ghrelin acts in the central nervous system as a potent orexigenic signal. Not only is ghrelin recognized as playing an important role in feeding circuits traditionally thought of as affecting body weight homeostasis, but an accumulating number of scientific studies now have identified ghrelin as being a key regulator of reward-based, hedonic eating behaviors. In the current article, we review ghrelin's orexigenic actions, the evidence linking ghrelin to food reward behavior, potential mechanisms by which ghrelin mediates reward-based eating behavior, and those studies suggesting an obligatory role for ghrelin in the changed eating behaviors induced by stress.
\end{abstract}

\section{Keywords}

Ghrelin; GHSR; hedonic; reward; eating; stress

\begin{abstract}
Ghrelin is a peptide hormone synthesized mainly by a distinct group of endocrine cells located within the gastric oxyntic mucosa (1). Ghrelin acts via the growth hormone secretagogue receptor (GHSR), a G-protein coupled receptor initially identified as the target of synthetic growth hormone secretagogues (2). GHSRs are expressed in numerous brain nuclei and peripheral tissues, where they mediate ghrelin's actions on a diverse group of processes and behaviors (3). These include roles in growth hormone secretion, blood glucose homeostasis, locomotor activity, gastrointestinal prokinesis and mood-related behaviors, among many others (3-5). In addition, ghrelin is essential for body weight and energy balance regulation (6-9) and is recognized as the only known orexigenic peptide hormone (3). Ghrelin was initially shown to stimulate food intake by activating homeostatic hypothalamic circuits (10). These homeostatic circuits provide a means by which ghrelin
\end{abstract}

(C) 2012 Society of Biological Psychiatry. Published by Elsevier Inc. All rights reserved.

Corresponding Author: Jeffrey M. Zigman, UT Southwestern Medical Center, 5323 Harry Hines Blvd, Dallas, TX 75390-9077, Phone -214-648-8621, FAX - 214-648-5612, jeffrey.zigman@utsouthwestern.edu.

Financial Disclosures

The authors report no biomedical financial interests or potential conflicts of interest.

Publisher's Disclaimer: This is a PDF file of an unedited manuscript that has been accepted for publication. As a service to our customers we are providing this early version of the manuscript. The manuscript will undergo copyediting, typesetting, and review of the resulting proof before it is published in its final citable form. Please note that during the production process errors may be discovered which could affect the content, and all legal disclaimers that apply to the journal pertain. 
and other signals of energy availability and gastrointestinal tract activity can interact with the central nervous system to modulate food intake and energy expenditure and ultimately, maintain a set body weight (11). Recent evidence shows that ghrelin also regulates mesolimbic circuitries and, as a consequence, various non-homeostatic, hedonic aspects of eating (12-14). Hedonic, or reward-based eating, involves behaviors which lead to the consumption of pleasurable foods, which individuals are motivated to efficiently obtain (15). Here, we review the role of ghrelin as an orexigenic hormone, with a focus on ghrelin's impact on reward-based eating. We also discuss physiological implications of this action and in particular, the role of ghrelin as a mediator of stress-induced, reward-based eating behaviors.

\section{Orexigenic actions of ghrelin and its relationship with body weight}

Ghrelin's effects on eating are well-established [as reviewed (8)]. Ghrelin both signals and helps respond to states of energy insufficiency. Circulating ghrelin increases before meals to levels that stimulate food intake when generated by peripheral administration of the hormone (8). Its levels also rise following food deprivation and after weight loss linked to exercise and cachexia (16-22). Infusions of ghrelin or GHSR agonists increase body weight via pro-orexigenic actions and/or decreases in energy expenditure (10, 23-26). Ghrelin's orexigenic actions are rapid and trigger eating even at times of minimal spontaneous food intake (8). After an overnight fast, ghrelin antagonists block rebound overeating (27). Chronic treatment with exogenous ghrelin also enhances feeding and body weight gain, suggesting that ghrelin participates in long-term body weight regulation (25). Although some studies have demonstrated little to no effect of genetic or pharmacologic interference with ghrelin signaling on body weight and food intake $(28,29)$, other studies suggest that intact ghrelin signaling is required for normal eating behaviors and body weight responses, especially to hedonically rewarding high-fat diets (HFD) $(6,7,27,30)$. For instance, GHSR deficiency reduces food intake, body weight and adiposity upon early HFD exposure $(6,30)$. Ghrelin knockout mice exposed to HFD early in life show a similar phenotype (7). Certain, but not all, of the published GHSR-deficient mouse models also manifest reduced body weights upon exposure to standard chow diet $(6,9,31)$. Interestingly, in one study, while genetic deletion of ghrelin or GHSR alone resulted in no observed change in body weight upon exposure to standard chow, genetic deletion of both did decrease body weight, suggesting the existence of other molecular components of the ghrelin signaling system (9).

Ghrelin is also relevant for human body weight regulation (32). Ghrelin administration increases food intake in healthy individuals, and pre-prandial ghrelin surges are observed as many times per day as meals are provided to subjects exposed to habituated feeding schedules $(8,17)$. In addition, ghrelin appears relevant for some types of human obesity (32). Ghrelin levels rise in individuals after weight loss induced by dieting, and such may contribute to the rebound weight gain commonly observed in dieters (33). Also, the marked and prolonged weight loss induced by Roux-en-Y gastric bypass (RYGB) surgery is thought by many to be enhanced by post-bypass reductions in circulating ghrelin. As $1^{\text {st }}$ reported in 2002, 24-hr ghrelin profiles of RYGB subjects were $>70 \%$ lower than those of obese controls (33). Most subsequent RYGB trials have confirmed this atypical, relative ghrelin deficiency, as opposed to the rise in ghrelin observed with dieting or other instances of energy insufficiency (34-36). While most obese individuals have reduced baseline levels of circulating ghrelin as compared to normal subjects (32), in Prader-Willi Syndrome, elevated ghrelin levels exist and have been postulated by some to contribute to the unrelenting hyperphagia and weight gain characteristic of this syndromic form of obesity $(37,38)$.

These findings have supported the notion that blocking ghrelin action may be an effective strategy to reduce body weight or prevent the development of obesity (39). In fact, reduction 
of bioavailable ghrelin or daily administration of GHSR antagonists to diet-induced obese mice lower body weights and reduce food intake (39-42). Similarly, administration to mice of an antagonist of ghrelin $O$-acyltransferase, which catalyzes a crucial post-translational modification of ghrelin, markedly reduces weight gain in response to a diet enriched in medium chain triglycerides (43).

On the opposite end of the spectrum, rodents and/or humans with cachexia of various etiologies and anorexia nervosa have high circulating ghrelin $(19,22)$. We hypothesize that the endogenous ghrelin elevations associated with cachexia and anorexia nervosa serve a protective function against what otherwise would be a more severe phenotype. In such regard, ghrelin would be acting in a similar protective role as has been postulated during psychosocial stress; namely, the high ghrelin induced by stress helps to minimize stressassociated depression-like behaviors (see below for further discussion) (44). In fact, although elevations in ghrelin occur naturally in the setting of cachexia induced, for instance, by administration of the chemotherapeutic agent cisplatin to rats or the implantation of sarcomas in rats, pharmacologically raising ghrelin levels in these models even further improves lean body mass and increases food consumption $(22,45)$. Therefore, alterations in the ghrelin system appear relevant for different extremes of body weight, and future therapies for a variety of body weight disorders may include those that target ghrelinbased eating behaviors.

\section{Ghrelin's effects on hedonic aspects of eating}

The mechanisms by which ghrelin promotes food intake are multifaceted, and include not only stimulating intake of food via homeostatic mechanisms, but also enhancing the rewarding properties of certain foods such that the host puts forth extra effort to efficiently obtain the pleasurable food $(27,46-51)$. As discussed below, GHSR expression in and ghrelin interaction with several brain regions involved in reward processing support the concept that ghrelin regulates these extra-homeostatic aspects of eating $(12,52)$. Observation of these expression patterns has led investigators to better characterize ghrelin's effects on food reward behavior.

Several studies have examined a role for ghrelin in defining food preference. Ghrelin shifts food preference towards diets rich in fat $(25,49)$. Similarly, ghrelin increases consumption of palatable saccharin solution and increases preference for saccharin-flavored foods in wild-type but not GHSR-deficient mice (47). Reinforcing these findings, GHSR-deficient mice and GHSR antagonist-treated rats consume less peanut butter and Ensure ${ }^{\circledR}$ but do not decrease consumption of regular chow in a free choice protocol (48). Likewise, GHSR antagonist temporarily and selectively decreases intake by rats of $5 \%$ sucrose solution in a sucrose vs. water two-bottle-choice drinking protocol (53). GHSR antagonist also blunts saccharin solution self-administration by mice (53).

In addition to enhancing preference for sweet and fatty foods, ghrelin mediates more complex, reward-based eating behaviors. For instance, in the food conditioned place preference (CPP) test, the amount of time animals spend in an environment with which they have been conditioned to find a pleasurable diet is compared to time spent in a distinct environment associated with regular chow or no food. Pharmacologic administration of ghrelin and endogenous increases in ghrelin induced by caloric restriction both enable acquisition of CPP for HFD $(27,46,50)$. Conversely, wild-type mice treated with GHSR antagonist during the conditioning period and GHSR-null mice both failed to show CPP for HFD normally observed under calorie restriction (27). GHSR antagonist also blocks CPP for chocolate pellets in satiated rats (48). 
Ghrelin's effects on reward-based eating behavior also have been assessed using operant lever-pressing or operant nose-poking, which focus on motivational aspects of reward (27, $51,54)$. Ghrelin increases operant lever-pressing for sucrose, peanut-butter-flavored sucrose, and HFD pellets in rodents $(27,51,55,56)$. Conversely, GHSR antagonist reduces operant responding for $5 \%$ sucrose solution (53). Of note, diet-induced obesity reduces ghrelinstimulated operant responding for food rewards (51). In such regard, the blunting effect of diet-induced obesity on ghrelin's mediation of food reward behavior is similar to the resistance to ghrelin's orexigenic actions observed in diet-induced obese mice $(57,58)$.

Ghrelin's actions on food reward also are relevant in humans. In particular, ghrelin administration to human subjects during functional magnetic resonance imaging increases the neural response to food pictures in several brain regions implicated in hedonic feeding, including the amygdala, orbitofrontal cortex, hippocampus, striatum, and ventral tegmental area $($ VTA) $(59,60)$.

\section{Neuronal substrates and circuits mediating ghrelin's actions on food reward}

Over the last decade, several investigators have worked to determine the neuronal populations and intracellular signaling cascades responsible for modulating ghrelin's actions on homeostatic eating, growth hormone release and blood glucose homeostasis [as reviewed in $(2,61)]$. The neuronal substrates and circuits mediating ghrelin-induced food reward behaviors are just beginning to be elucidated, and will be discussed here (Figure 1).

\section{Dopamine}

Dopaminergic neurons emanating from the VTA project to the nucleus accumbens (NAc), amygdala, prefrontal cortex and hippocampus $(11,15)$. These projections comprise the mesolimbic pathway and strongly drive reward behaviors of various types. Of relevance, GHSRs are highly expressed in the VTA, including dopaminergic VTA neurons $(12,52)$. Upon ghrelin administration, VTA-lesioned rats specifically consume less peanut butter but eat equal amounts of regular chow, as compared to sham-lesioned animals(48). VTAlesioned rats spend less time than sham-lesioned rats exploring tubes containing peanut butter in response to intracerebroventricular ghrelin administration (48). Selective knockdown of GHSR expression in transgenic rats expressing an antisense GHSR transcript in tyrosine hydroxylase-containing cells (which include the dopaminergic VTA neurons) decreases food intake (62). Also, chronic ghrelin administration influences gene expression of several dopamine receptors within the VTA-NAc circuit (63).

Ghrelin can directly affect dopaminergic VTA neuronal activity $(12,52)$. For instance, exogenous ghrelin induces dopamine release from VTA neurons that project to the NAc, and ghrelin increases action potential frequency in these neurons $(5,12,14,64,65)$.

Furthermore, intra-VTA administration of ghrelin and/or GHSR antagonists modulates intake of freely-available regular chow, food preference, motivated food reward behavior, and other actions including locomotion. As such, ghrelin microinjection into the VTA acutely increases intake of freely-available food, while VTA microinjection of a GHSR antagonist decreases food intake in response to peripheral ghrelin $(12,13)$. Chronic ghrelin administration into the VTA dose-dependently increases intake of freely-available regular chow and increases body weight (66). Direct ghrelin microinjection into the VTA also increases intake of peanut butter over regular chow (48). Similarly, intra-VTA administration of a GHSR antagonist selectively reduces intake of HFD, and has no effect on intake of less-preferred protein-rich or carbohydrate-rich diets, to which they have equal access (66). VTA microinjection of ghrelin increases operant lever-pressing for sucrose 
rewards and banana-flavored pellets $(12,13,48,55,56,67)$, while VTA microinjection of a GHSR antagonist decreases operant responding for sucrose normally induced by an overnight fast $(12,55)$. Analogous effects are observed in food-restricted rats, in which chronic intra-VTA ghrelin delivery enhances while chronic intra-VTA GHSR antagonist delivery blunts operant responding for chocolate-flavored pellets (66). Furthermore, striatal dopamine depletion, as induced by unilateral VTA delivery of the neurotoxin 6hydroxydopamine, reduces intra-VTA-administered ghrelin's effects on operant leverpressing for food rewards (67). The locomotor stimulatory effects of ghrelin also are blocked upon intra-VTA GHSR antagonist administration (68).

In studies to investigate the role of direct ghrelin action on the VTA, we crossed GHSR-null mice, which contain a loxP-flanked transcriptional blocking cassette inserted into the GHSR gene, to mice in which Cre recombinase expression is driven by the tyrosine hydroxylase promoter (50). Mice containing two copies of the GHSR-null allele and one copy of the Cre transgene express GHSRs selectively in tyrosine hydroxylase-containing cells normally programmed to express both GHSR and tyrosine hydroxylase. These include, although are not restricted to, a subset of VTA dopaminergic neurons. Ghrelin signaling specifically in these predominantly dopaminergic neurons not only mediates administered ghrelin's ability to stimulate intake of freely-available regular chow, but also is sufficient to mediate its actions on CPP for HFD (50). Altogether, these many studies highly suggest a critical role of GHSR-containing dopaminergic VTA neurons for ghrelin's actions on food intake and food reward.

\section{Opioids}

Opioids likely play a prominent regulatory role for ghrelin-responsive VTA dopaminergic neurons. Prior intracerebroventricular administration of the $\mu$-opioid receptor-preferring antagonist, naltrexone, blocks operant responding for sucrose pellets by rats given ghrelin intracerebroventricularly (56). More specifically, central ghrelin infusion increases $\mu$-opioid receptor mRNA expression within the VTA (56). Also, operant responding for sucrose induced by direct VTA microinjection of ghrelin is blocked upon prior VTA microinjection of naltrexone (56). Interestingly, while increased ghrelin-induced intake of freely-available chow also is blocked by naltrexone when both compounds are administered intracerebroventricularly, such is not observed upon direct VTA microinjection of the compounds (56). As such, opioids are critical in ghrelin's actions on both food intake and food reward, but the anatomic locations of the circuits controlling these processes are likely at least partly distinct.

\section{NPY}

Ghrelin-responsive VTA neurons may also be impacted by arcuate hypothalamic neuropeptide Y (NPY) neurons. Similar to the aforementioned naltrexone studies, the NPYY1 receptor antagonist LY1229U91 (LY) blocks ghrelin-induced operant responding for sucrose pellets when both LY and ghrelin are administered intracerebroventricularly, although LY is ineffective upon intra-VTA administration of both it and ghrelin (56). In contrast to naltrexone, LY blunts ghrelin-stimulated intake of freely-available chow whether both are injected intracerebroventricularly or intra-VTA (56). Therefore, just as was observed for opioids, NPY signaling is important to ghrelin's orexigenic actions and its actions on food reward, although the circuits controlling these processes are at least partly anatomically distinct.

\section{Orexins}

Another likely input into the ghrelin-VTA circuit are the orexins (hypocretins). Orexins are well-characterized neuropeptide participants in rewarding behaviors. Ghrelin action on food 
reward requires intact signaling by orexin, as evidenced by the failure of orexin-knockout mice or wild-type mice given orexin receptor 1 antagonist SB-334867 intraperitoneally to acquire CPP for HFD in response to ghrelin treatment (27). Once again demonstrating the complexity of these neuronal circuits, SB-334867-pretreated mice and orexin-deficient mice both display full orexigenic responses to ghrelin (27).

\section{nAChR}

Ghrelin's actions on food reward also are impacted by cholinergic signaling. Intraperitoneal administration of the non-selective, centrally-active nicotine acetylcholine receptor (nAchR) antagonist mecamylamine decreases fasting-induced food intake in rodents and decreases the ability of a chocolate-based food reward to condition a place preference (69). More specifically, intraperitoneal injection of mecamylamine reduces intracerebroventricularlyadministered ghrelin-induced food intake in rats (69). Intraperitoneal administration of mecamylamine or 18-methoxycoronaridine, a selective antagonist of a $3 \beta 4$ nicotinic receptors, decreases intracerebroventricular ghrelin-induced dopamine overflow in the NAc (5), intra-VTA administered ghrelin-induced dopamine overflow in the NAc (64), and/or intra-VTA-administered ghrelin-induced food intake (69). Also, chronic intracerebroventricular ghrelin modulates $\mathrm{nAChRb} 2$ and $\mathrm{nAChRa} 3$ gene expression in mesolimbic pathways (63). The most direct evidence of cholinergic influence on ghrelin's mediation of food reward comes from a study in which mecamylamine blunted ghrelininduced acquisition of food CPP (47), and another in which peripheral administration of 18methoxycoronaridine blocked intra-VTA ghrelin-induced increases in 5\% sucrose solution intake during a two-bottle open access protocol (64).

Studies on the role of nAChR signaling in ghrelin action have uncovered yet another likely direct central site of action - the laterodorsal tegmental area (LDTg) -for ghrelin's effects on food reward. The LDTg is a known site of GHSR expression $(52,69,70)$, wherein GHSR mRNA co-localizes with choline acetyltransferase mRNA (69). Intra-VTA administration of the $\mathrm{nAChR}$ antagonist, $\mathrm{a}$-conotoxin MII, blocks NAc dopamine overflow induced by LDTgadministered ghrelin (65). Thus, for at least some of its effects, ghrelin may act directly on LDTg cholinergic neurons that project to the VTA.

\section{Glutamate}

Pharmacological suppression of glutamatergic signaling, as achieved by intra-VTA administration of the N-methyl-D-aspartic acid receptor antagonist AP5, blocks ghrelininduced dopamine overflow in the NAc and ghrelin-induced locomotor stimulation (68). Thus it is likely that glutamatergic input to the VTA also affects ghrelin's ability to modulate food reward behavior.

\section{Endocannabinoids}

Endocannabinoids increase food intake and motivation to consume palatable foods (71). Central injection of ghrelin to endocannabinoid receptor type 1 knockout mice fails to increase food intake, suggesting that the endocannabinoid signaling system is necessary for ghrelin's orexigenic effect and may also mediate hedonic actions of ghrelin (72).

\section{Role of ghrelin as a mediator of stress-induced complex eating behaviors}

The physiologic significance of ghrelin's effects on food reward seems most apparent during situations in which plasma ghrelin is normally elevated, such as periods of energy insufficiency $(73,74)$. For instance, CPP for HFD is induced in wild-type mice by prolonged caloric restriction $(27,54)$, while GHSR antagonist administration to wild-type mice or alternatively, genetic deletion of GHSRs, prevents this caloric restriction-associated food 
reward behavior $(27,54)$. GHSR antagonist administration also prevents caloric restrictionassociated operant lever pressing for sucrose in rats (63). One might argue that the ghrelin system has evolved to help animals cope with states of energy insufficiency by favoring reward-based eating of palatable calorie dense foods.

Elevations of ghrelin also are observed upon stress $(44,75-81)$. For instance, elevations in gastric ghrelin gene expression and plasma ghrelin occur in rodents' responses to tail pinch stress and water avoidance stress $(75,76)$. Plasma ghrelin elevations also occur in rodents stressed by exposure to a continuously flooded cage or to cold environment $(44,50,77,82)$. The chronic social defeat stress (CSDS) procedure, which subjects male mice to repeated bouts of social subordination by an older and larger aggressor, leads to sustained plasma ghrelin elevations $(44,50,83)$. Similarly, exposure of mice to a 14-day chronic unpredictable stress protocol raises plasma ghrelin (81). Humans subjected acutely to psychosocial stress or to the standardized trier social stress test also display increased plasma ghrelin $(78,80)$. The mechanisms responsible for this stress-associated increase in circulating ghrelin have not yet been determined but may be mediated via a sympathoadrenal response, as suggested by studies linking activation of the sympathetic nervous system and/or release of catecholamines to ghrelin secretion and to a coordinated behavioral stress response (84-86).

Most humans upon stress report a change in their eating habits - with some eating more and some eating less than prior to the stress $(87,88)$. Furthermore, humans experience increases in the intake of highly palatable foods independent of their general food intake response to the stress $(87,88)$. The complex eating behaviors that are associated with stress likely contribute to the increased prevalence of overweight and obese among individuals exposed to stress. Interestingly, stress-induced elevations in plasma ghrelin found in "high emotional eaters" -- so-called due to their experienced food cravings and increased consumption of foods high in carbohydrates and fats in response to negative emotions and stress - fail to decline acutely following food consumption (80). This is unlike the ghrelin response observed upon food intake in individuals who report little change in their eating habits upon stress (80), and thus further suggests a role for ghrelin in stress-based eating behaviors.

We have used CSDS to specifically investigate the role of ghrelin on stress-induced alterations in food reward behavior. CSDS, which as mentioned above elevates circulating ghrelin, is associated with hyperphagia of freely-available regular chow both during and for at least one month after the defeat period $(44,89,90)$. This hyperphagia, which is not observed in mice lacking GHSRs, may contribute to the higher body weight gain observed in CSDS-exposed wild-type mice $(44,89,90)$. Not only does CSDS induce a hyperphagic response in wild-type mice, but it also increases CPP for HFD (50). Such a stress-induced food reward response relies on ghrelin signaling, as CPP for HFD is not observed in CSDSexposed GHSR-null mice (50). Furthermore, expression of GHSRs selectively in tyrosine hydroxylase-containing neurons (which, as described above, include dopaminergic VTA neurons) is permissive for the induction of hedonic eating behaviors by the CSDS protocol (50). It is also possible that glucocorticoids play a supportive role in ghrelin's mediation of stress-induced reward-based eating, as higher corticosterone levels are observed in wild-type mice exposed to CSDS than in similarly-treated GHSR-null littermates. This seems relevant to the differences in stress-associated, reward-based eating observed in wild-type versus GHSR-null littermates since glucocorticoid secretion intensifies motivated behaviors and increases intake of highly palatable foods (88).

The above CSDS findings in wild-type and GHSR-null animals are in contrast to those observed in a chronic unpredictable stress mouse model of chronic stress (81). Although CSDS and chronic unpredictable stress both elevate plasma ghrelin, chronic unpredictable 
stress-exposed wild-type mice experience decreased food intake and body weight gain over the duration of the treatment period, while similarly-treated GHSR-deficient mice lack changes in these parameters (81). Further work is needed to clarify the potentially differential efficacies of ghrelin on food intake, food reward and body weight among different rodent models of stress-based eating (91-96) and among humans with differential eating behavioral responses to stress.

\section{Conclusions and perspectives}

Recent studies have revealed several intricacies regarding ghrelin's roles in modulation of food intake and the rewarding value of palatable foods. Most highlight the relevance of mesolimbic pathways in these effects. Interestingly, the effects of ghrelin on the mesolimbic system also extend to drug- and alcohol-driven behaviors, suggesting that ghrelin may be a link between food deprivation and/or stress with increases in the hedonic value of a wide range of rewards [as reviewed in (97-99)]. Ghrelin itself is known to be inherently rewarding (100). Mesolimbic pathways also are important for ghrelin's effects on mood. In particular, using mouse models, we have demonstrated that increasing circulating ghrelin levels by 10 days of calorie restriction or by acute subcutaneous injection produces an antidepressant-like response in the forced swim test (44). However, caloric restriction no longer induces this response in mice lacking GHSRs, suggesting that interference with ghrelin signaling negates the antidepressant-like behaviors associated with calorie restriction (44). Also, upon exposure to CSDS, GHSR-null mice manifest greater social isolation (another marker of depressive-like behavior) than do wild-type littermates (44). Thus, we have suggested that activation of ghrelin signaling pathways in response to chronic stress may be a homeostatic adaptation that helps individuals cope with stress. In addition to the other processes we were able to attribute to ghrelin-responsive catecholaminergic neurons, direct ghrelin signaling via GHSRs localized to catecholaminergic neurons (including those aforementioned VTA dopaminergic neurons) also is sufficient for the usual mood responses following chronic stress (50).

Given these many actions of ghrelin and seemingly overlapping neuronal circuits, one might envision a scenario whereby administration of ghrelin mimetic to individuals with anorexia nervosa undergoing re-feeding therapy would prevent relative drops in circulating ghrelin. The ensuing sustained tone in ghrelin-engaged circuits would then help stimulate food intake, minimize what might otherwise be worsened depression (a frequent co-morbid condition among anorexia nervosa subjects), and lead to a better sense of well-being (due to the inherent rewarding properties of ghrelin).

Conversely, the mesolimbic pathways regulating at least some of ghrelin's effects on homeostatic eating, hedonic eating, and mood may limit its effectiveness as a weight loss drug target. The intertwined nature of neuronal pathways mediating the coordinated behavioral stress response may predict the same fate as the anti-obesity drug Rimonabant, which did not gain FDA approval due to increased reports of severe depression, for other candidate anti-obesity compounds. Such seemingly closely linked behaviors highlight even further the importance of studies aimed at dissecting the neuroanatomical pathways controlling ghrelin's actions on eating behavior linked to body weight homeostasis, reward, stress and mood. Despite this potential drawback, we believe that all of the available data linking ghrelin to food reward behavior strongly support the concept of targeting the ghrelin system as a plausible strategy to treat and/or prevent the development of extremes of body weight. 


\section{Acknowledgments}

The authors would like to acknowledge the assistance of Dr. Michael Lutter for his many helpful comments during the preparation of this manuscript. This study was supported by the Florencio Fiorini Foundation, International Brain Research Organization and PICT2010-1954 grants to MP and by R01DA024680 and R01MH085298 NIH grants to JMZ.

\section{References}

1. Kojima M, Hosoda H, Date Y, Nakazato M, Matsuo H, Kangawa K. Ghrelin is a growth-hormonereleasing acylated peptide from stomach. Nature. 1999; 402:656-660. [PubMed: 10604470]

2. Cruz CR, Smith RG. The growth hormone secretagogue receptor. Vitam Horm. 2008; 77:47-88. [PubMed: 17983853]

3. Kojima M, Kangawa K. Ghrelin: structure and function. Physiol Rev. 2005; 85:495-522. [PubMed: 15788704]

4. Nogueiras R, Tschop MH, Zigman JM. Central nervous system regulation of energy metabolism: ghrelin versus leptin. Ann N Y Acad Sci. 2008; 1126:14-19. [PubMed: 18448790]

5. Jerlhag E, Egecioglu E, Dickson SL, Andersson M, Svensson L, Engel JA. Ghrelin stimulates locomotor activity and accumbal dopamine-overflow via central cholinergic systems in mice: implications for its involvement in brain reward. Addict Biol. 2006; 11:45-54. [PubMed: 16759336]

6. Zigman JM, Nakano Y, Coppari R, Balthasar N, Marcus JN, Lee CE, et al. Mice lacking ghrelin receptors resist the development of diet-induced obesity. J Clin Invest. 2005; 115:3564-3572. [PubMed: 16322794]

7. Wortley KE, del Rincon JP, Murray JD, Garcia K, Iida K, Thorner MO, et al. Absence of ghrelin protects against early-onset obesity. J Clin Invest. 2005; 115:3573-3578. [PubMed: 16322795]

8. Cummings DE. Ghrelin and the short- and long-term regulation of appetite and body weight. Physiol Behav. 2006; 89:71-84. [PubMed: 16859720]

9. Pfluger PT, Kirchner H, Gunnel S, Schrott B, Perez-Tilve D, Fu S, et al. Simultaneous deletion of ghrelin and its receptor increases motor activity and energy expenditure. Am J Physiol Gastrointest Liver Physiol. 2008; 294:G610-618. [PubMed: 18048479]

10. Nakazato M, Murakami N, Date Y, Kojima M, Matsuo H, Kangawa K, et al. A role for ghrelin in the central regulation of feeding. Nature. 2001; 409:194-198. [PubMed: 11196643]

11. Saper CB, Chou TC, Elmquist JK. The need to feed: homeostatic and hedonic control of eating. Neuron. 2002; 36:199-211. [PubMed: 12383777]

12. Abizaid A, Liu ZW, Andrews ZB, Shanabrough M, Borok E, Elsworth JD, et al. Ghrelin modulates the activity and synaptic input organization of midbrain dopamine neurons while promoting appetite. J Clin Invest. 2006; 116:3229-3239. [PubMed: 17060947]

13. Naleid AM, Grace MK, Cummings DE, Levine AS. Ghrelin induces feeding in the mesolimbic reward pathway between the ventral tegmental area and the nucleus accumbens. Peptides. 2005; 26:2274-2279. [PubMed: 16137788]

14. Jerlhag E, Egecioglu E, Dickson SL, Douhan A, Svensson L, Engel JA. Ghrelin administration into tegmental areas stimulates locomotor activity and increases extracellular concentration of dopamine in the nucleus accumbens. Addict Biol. 2007; 12:6-16. [PubMed: 17407492]

15. Hyman SE, Malenka RC, Nestler EJ. Neural mechanisms of addiction: the role of reward-related learning and memory. Annu Rev Neurosci. 2006; 29:565-598. [PubMed: 16776597]

16. Cummings DE, Foster KE. Ghrelin-leptin tango in body-weight regulation. Gastroenterology. 2003; 124:1532-1535. [PubMed: 12730891]

17. Cummings DE, Purnell JQ, Frayo RS, Schmidova K, Wisse BE, Weigle DS. A preprandial rise in plasma ghrelin levels suggests a role in meal initiation in humans. Diabetes. 2001; 50:1714-1719. [PubMed: 11473029]

18. Nagaya N, Uematsu M, Kojima M, Date Y, Nakazato M, Okumura H, et al. Elevated circulating level of ghrelin in cachexia associated with chronic heart failure: relationships between ghrelin and anabolic/catabolic factors. Circulation. 2001; 104:2034-2038. [PubMed: 11673342] 
19. Otto B, Cuntz U, Fruehauf E, Wawarta R, Folwaczny C, Riepl RL, et al. Weight gain decreases elevated plasma ghrelin concentrations of patients with anorexia nervosa. Eur J Endocrinol. 2001; 145:669-673. [PubMed: 11720888]

20. Tolle V, Kadem M, Bluet-Pajot MT, Frere D, Foulon C, Bossu C, et al. Balance in ghrelin and leptin plasma levels in anorexia nervosa patients and constitutionally thin women. J Clin Endocrinol Metab. 2003; 88:109-116. [PubMed: 12519838]

21. Wisse BE, Frayo RS, Schwartz MW, Cummings DE. Reversal of cancer anorexia by blockade of central melanocortin receptors in rats. Endocrinology. 2001; 142:3292-3301. [PubMed: 11459770]

22. Garcia JM, Cata JP, Dougherty PM, Smith RG. Ghrelin prevents cisplatin-induced mechanical hyperalgesia and cachexia. Endocrinology. 2008; 149:455-460. [PubMed: 17962345]

23. Strassburg S, Anker SD, Castaneda TR, Burget L, Perez-Tilve D, Pfluger PT, et al. Long-term effects of ghrelin and ghrelin receptor agonists on energy balance in rats. Am J Physiol Endocrinol Metab. 2008; 295:E78-84. [PubMed: 18460598]

24. Asakawa A, Inui A, Kaga T, Yuzuriha H, Nagata T, Ueno N, et al. Ghrelin is an appetitestimulatory signal from stomach with structural resemblance to motilin. Gastroenterology. 2001; 120:337-345. [PubMed: 11159873]

25. Tschop M, Smiley DL, Heiman ML. Ghrelin induces adiposity in rodents. Nature. 2000; 407:908913. [PubMed: 11057670]

26. Wren AM, Small CJ, Abbott CR, Dhillo WS, Seal LJ, Cohen MA, et al. Ghrelin causes hyperphagia and obesity in rats. Diabetes. 2001; 50:2540-2547. [PubMed: 11679432]

27. Perello M, Sakata I, Birnbaum S, Chuang JC, Osborne-Lawrence S, Rovinsky SA, et al. Ghrelin increases the rewarding value of high-fat diet in an orexin-dependent manner. Biol Psychiatry. 2010; 67:880-886. [PubMed: 20034618]

28. Sun Y, Butte NF, Garcia JM, Smith RG. Characterization of adult ghrelin and ghrelin receptor knockout mice under positive and negative energy balance. Endocrinology. 2008; 149:843-850. [PubMed: 18006636]

29. Albarran-Zeckler RG, Sun Y, Smith RG. Physiological roles revealed by ghrelin and ghrelin receptor deficient mice. Peptides. 2011

30. Perello M, Scott MM, Sakata I, Lee CE, Chuang JC, Osborne-Lawrence S, et al. Functional implications of limited leptin receptor and ghrelin receptor co-expression in the brain. J Comp Neurol. 2011

31. Sun Y, Wang P, Zheng H, Smith RG. Ghrelin stimulation of growth hormone release and appetite is mediated through the growth hormone secretagogue receptor. Proc Natl Acad Sci U S A. 2004; 101:4679-4684. [PubMed: 15070777]

32. Hillman JB, Tong J, Tschop M. Ghrelin biology and its role in weight-related disorders. Discov Med. 2011; 11:521-528. [PubMed: 21712018]

33. Cummings DE, Weigle DS, Frayo RS, Breen PA, Ma MK, Dellinger EP, et al. Plasma ghrelin levels after diet-induced weight loss or gastric bypass surgery. N Engl J Med. 2002; 346:16231630. [PubMed: 12023994]

34. Cummings DE, Overduin J, Shannon MH, Foster-Schubert KE. Hormonal mechanisms of weight loss and diabetes resolution after bariatric surgery. Surg Obes Relat Dis. 2005; 1:358-368. [PubMed: 16925248]

35. Thaler JP, Cummings DE. Minireview: Hormonal and metabolic mechanisms of diabetes remission after gastrointestinal surgery. Endocrinology. 2009; 150:2518-2525. [PubMed: 19372197]

36. Lee H, Te C, Koshy S, Teixeira JA, Pi-Sunyer FX, Laferrere B. Does ghrelin really matter after bariatric surgery? Surg Obes Relat Dis. 2006; 2:538-548. [PubMed: 17015210]

37. Cummings DE, Clement K, Purnell JQ, Vaisse C, Foster KE, Frayo RS, et al. Elevated plasma ghrelin levels in Prader Willi syndrome. Nat Med. 2002; 8:643-644. [PubMed: 12091883]

38. Tauber M, Conte Auriol F, Moulin P, Molinas C, Delagnes V, Salles JP. Hyperghrelinemia is a common feature of Prader-Willi syndrome and pituitary stalk interruption: a pathophysiological hypothesis. Horm Res. 2004; 62:49-54. [PubMed: 15192277] 
39. Zorrilla EP, Iwasaki S, Moss JA, Chang J, Otsuji J, Inoue K, et al. Vaccination against weight gain. Proc Natl Acad Sci U S A. 2006; 103:13226-13231. [PubMed: 16891413]

40. Shearman LP, Wang SP, Helmling S, Stribling DS, Mazur P, Ge L, et al. Ghrelin neutralization by a ribonucleic acid-SPM ameliorates obesity in diet-induced obese mice. Endocrinology. 2006; 147:1517-1526. [PubMed: 16339202]

41. Rudolph J, Esler WP, O’Connor S, Coish PD, Wickens PL, Brands M, et al. Quinazolinone derivatives as orally available ghrelin receptor antagonists for the treatment of diabetes and obesity. J Med Chem. 2007; 50:5202-5216. [PubMed: 17887659]

42. Esler WP, Rudolph J, Claus TH, Tang W, Barucci N, Brown SE, et al. Small-molecule ghrelin receptor antagonists improve glucose tolerance, suppress appetite, and promote weight loss. Endocrinology. 2007; 148:5175-5185. [PubMed: 17656463]

43. Barnett BP, Hwang Y, Taylor MS, Kirchner H, Pfluger PT, Bernard V, et al. Glucose and weight control in mice with a designed ghrelin O-acyltransferase inhibitor. Science. 2010; 330:16891692. [PubMed: 21097901]

44. Lutter M, Sakata I, Osborne-Lawrence S, Rovinsky SA, Anderson JG, Jung S, et al. The orexigenic hormone ghrelin defends against depressive symptoms of chronic stress. Nat Neurosci. 2008; 11:752-753. [PubMed: 18552842]

45. DeBoer MD, Zhu XX, Levasseur P, Meguid MM, Suzuki S, Inui A, et al. Ghrelin treatment causes increased food intake and retention of lean body mass in a rat model of cancer cachexia. Endocrinology. 2007; 148:3004-3012. [PubMed: 17347304]

46. Disse E, Bussier AL, Deblon N, Pfluger PT, Tschop MH, Laville M, et al. Systemic ghrelin and reward: effect of cholinergic blockade. Physiol Behav. 2011; 102:481-484. [PubMed: 21163280]

47. Disse E, Bussier AL, Veyrat-Durebex C, Deblon N, Pfluger PT, Tschop MH, et al. Peripheral ghrelin enhances sweet taste food consumption and preference, regardless of its caloric content. Physiol Behav. 2010; 101:277-281. [PubMed: 20515700]

48. Egecioglu E, Jerlhag E, Salome N, Skibicka KP, Haage D, Bohlooly YM, et al. Ghrelin increases intake of rewarding food in rodents. Addict Biol. 2010; 15:304-311. [PubMed: 20477752]

49. Shimbara T, Mondal MS, Kawagoe T, Toshinai K, Koda S, Yamaguchi H, et al. Central administration of ghrelin preferentially enhances fat ingestion. Neurosci Lett. 2004; 369:75-79. [PubMed: 15380311]

50. Chuang JC, Perello M, Sakata I, Osborne-Lawrence S, Savitt JM, Lutter M, et al. Ghrelin mediates stress-induced food-reward behavior in mice. J Clin Invest. 2011; 121:2684-2692. [PubMed: 21701068]

51. Finger BC, Dinan TG, Cryan JF. Diet-induced obesity blunts the behavioural effects of ghrelin: studies in a mouse-progressive ratio task. Psychopharmacology (Berl). 2011

52. Zigman JM, Jones JE, Lee CE, Saper CB, Elmquist JK. Expression of ghrelin receptor mRNA in the rat and the mouse brain. J Comp Neurol. 2006; 494:528-548. [PubMed: 16320257]

53. Landgren S, Simms JA, Thelle DS, Strandhagen E, Bartlett SE, Engel JA, et al. The ghrelin signalling system is involved in the consumption of sweets. PLoS One. 2011; 6:e18170. [PubMed: 21448464]

54. Chruscinski AJ, Rohrer DK, Schauble E, Desai KH, Bernstein D, Kobilka BK. Targeted disruption of the beta2 adrenergic receptor gene. J Biol Chem. 1999; 274:16694-16700. [PubMed: 10358008]

55. Skibicka KP, Hansson C, Alvarez-Crespo M, Friberg PA, Dickson SL. Ghrelin directly targets the ventral tegmental area to increase food motivation. Neuroscience. 2011; 180:129-137. [PubMed: 21335062]

56. Skibicka KP, Shirazi RH, Hansson C, Dickson SL. Ghrelin Interacts with Neuropeptide Y Y1 and Opioid Receptors to Increase Food Reward. Endocrinology. 2011

57. Perreault M, Istrate N, Wang L, Nichols AJ, Tozzo E, Stricker-Krongrad A. Resistance to the orexigenic effect of ghrelin in dietary-induced obesity in mice: reversal upon weight loss. Int $\mathbf{J}$ Obes Relat Metab Disord. 2004; 28:879-885. [PubMed: 15111983]

58. Briggs DI, Enriori PJ, Lemus MB, Cowley MA, Andrews ZB. Diet-induced obesity causes ghrelin resistance in arcuate NPY/AgRP neurons. Endocrinology. 2010; 151:4745-4755. [PubMed: 20826561] 
59. Neary MT, Batterham RL. Gaining new insights into food reward with functional neuroimaging. Forum Nutr. 2010; 63:152-163. [PubMed: 19955783]

60. Malik S, McGlone F, Bedrossian D, Dagher A. Ghrelin modulates brain activity in areas that control appetitive behavior. Cell Metab. 2008; 7:400-409. [PubMed: 18460331]

61. Schellekens H, Dinan TG, Cryan JF. Lean mean fat reducing "ghrelin" machine: hypothalamic ghrelin and ghrelin receptors as therapeutic targets in obesity. Neuropharmacology. 2010; 58:2-16. [PubMed: 19573543]

62. Shuto Y, Shibasaki T, Otagiri A, Kuriyama H, Ohata H, Tamura H, et al. Hypothalamic growth hormone secretagogue receptor regulates growth hormone secretion, feeding, and adiposity. J Clin Invest. 2002; 109:1429-1436. [PubMed: 12045256]

63. Skibicka KP, Hansson C, Egecioglu E, Dickson SL. Role of ghrelin in food reward: impact of ghrelin on sucrose self-administration and mesolimbic dopamine and acetylcholine receptor gene expression. Addict Biol. 2012; 17:95-107. [PubMed: 21309956]

64. McCallum SE, Taraschenko OD, Hathaway ER, Vincent MY, Glick SD. Effects of 18methoxycoronaridine on ghrelin-induced increases in sucrose intake and accumbal dopamine overflow in female rats. Psychopharmacology (Berl). 2011; 215:247-256. [PubMed: 21210086]

65. Jerlhag E, Egecioglu E, Dickson SL, Svensson L, Engel JA. Alpha-conotoxin MII-sensitive nicotinic acetylcholine receptors are involved in mediating the ghrelin-induced locomotor stimulation and dopamine overflow in nucleus accumbens. Eur Neuropsychopharmacol. 2008; 18:508-518. [PubMed: 18343642]

66. King SJ, Isaacs AM, O'Farrell E, Abizaid A. Motivation to obtain preferred foods is enhanced by ghrelin in the ventral tegmental area. Horm Behav. 2011; 60:572-580. [PubMed: 21872601]

67. Weinberg ZY, Nicholson ML, Currie PJ. 6-Hydroxydopamine lesions of the ventral tegmental area suppress ghrelin's ability to elicit food-reinforced behavior. Neurosci Lett. 2011; 499:70-73. [PubMed: 21640160]

68. Jerlhag E, Egecioglu E, Dickson SL, Engel JA. Glutamatergic regulation of ghrelin-induced activation of the mesolimbic dopamine system. Addict Biol. 2011; 16:82-91. [PubMed: 20579004]

69. Dickson SL, Hrabovszky E, Hansson C, Jerlhag E, Alvarez-Crespo M, Skibicka KP, et al. Blockade of central nicotine acetylcholine receptor signaling attenuate ghrelin-induced food intake in rodents. Neuroscience. 2010; 171:1180-1186. [PubMed: 20933579]

70. Guan XM, Yu H, Palyha OC, McKee KK, Feighner SD, Sirinathsinghji DJ, et al. Distribution of mRNA encoding the growth hormone secretagogue receptor in brain and peripheral tissues. Brain Res Mol Brain Res. 1997; 48:23-29. [PubMed: 9379845]

71. Harrold JA, Williams G. The cannabinoid system: a role in both the homeostatic and hedonic control of eating? Br J Nutr. 2003; 90:729-734. [PubMed: 13129440]

72. Kola B, Farkas I, Christ-Crain M, Wittmann G, Lolli F, Amin F, et al. The orexigenic effect of ghrelin is mediated through central activation of the endogenous cannabinoid system. PLoS One. 2008; 3:e1797. [PubMed: 18335063]

73. Figlewicz DP, Higgins MS, Ng-Evans SB, Havel PJ. Leptin reverses sucrose-conditioned place preference in food-restricted rats. Physiol Behav. 2001; 73:229-234. [PubMed: 11399316]

74. Figlewicz DP, Benoit SC. Insulin, leptin, and food reward: update 2008. Am J Physiol Regul Integr Comp Physiol. 2009; 296:R9-R19. [PubMed: 18945945]

75. Asakawa A, Inui A, Kaga T, Yuzuriha H, Nagata T, Fujimiya M, et al. A role of ghrelin in neuroendocrine and behavioral responses to stress in mice. Neuroendocrinology. 2001; 74:143147. [PubMed: 11528215]

76. Kristenssson E, Sundqvist M, Astin M, Kjerling M, Mattsson H, Dornonville de la Cour C, et al. Acute psychological stress raises plasma ghrelin in the rat. Regul Pept. 2006; 134:114-117. [PubMed: 16540188]

77. Ochi M, Tominaga K, Tanaka F, Tanigawa T, Shiba M, Watanabe T, et al. Effect of chronic stress on gastric emptying and plasma ghrelin levels in rats. Life Sci. 2008; 82:862-868. [PubMed: 18343456] 
78. Rouach V, Bloch M, Rosenberg N, Gilad S, Limor R, Stern N, et al. The acute ghrelin response to a psychological stress challenge does not predict the post-stress urge to eat. Psychoneuroendocrinology. 2007; 32:693-702. [PubMed: 17560728]

79. Chuang JC, Zigman JM. Ghrelin's Roles in Stress, Mood, and Anxiety Regulation. Int J Pept. 2010

80. Raspopow K, Abizaid A, Matheson K, Anisman H. Psychosocial stressor effects on cortisol and ghrelin in emotional and non-emotional eaters: influence of anger and shame. Horm Behav. 2010; 58:677-684. [PubMed: 20540943]

81. Patterson ZR, Ducharme R, Anisman H, Abizaid A. Altered metabolic and neurochemical responses to chronic unpredictable stressors in ghrelin receptor-deficient mice. Eur J Neurosci. 2010; 32:632-639. [PubMed: 20597975]

82. Stengel A, Wang L, Tache Y. Stress-related alterations of acyl and desacyl ghrelin circulating levels: Mechanisms and functional implications. Peptides. 2011

83. Nestler EJ, Hyman SE. Animal models of neuropsychiatric disorders. Nat Neurosci. 2010; 13:1161-1169. [PubMed: 20877280]

84. Zhao TJ, Sakata I, Li RL, Liang G, Richardson JA, Brown MS, et al. Ghrelin secretion stimulated by \{beta\}1-adrenergic receptors in cultured ghrelinoma cells and in fasted mice. Proc Natl Acad Sci U S A. 2010; 107:15868-15873. [PubMed: 20713709]

85. Mundinger TO, Cummings DE, Taborsky GJ Jr . Direct stimulation of ghrelin secretion by sympathetic nerves. Endocrinology. 2006; 147:2893-2901. [PubMed: 16527847]

86. Sgoifo A, Koolhaas J, De Boer S, Musso E, Stilli D, Buwalda B, et al. Social stress, autonomic neural activation, and cardiac activity in rats. Neurosci Biobehav Rev. 1999; 23:915-923. [PubMed: 10580306]

87. Gibson EL. Emotional influences on food choice: sensory, physiological and psychological pathways. Physiol Behav. 2006; 89:53-61. [PubMed: 16545403]

88. Dallman MF. Stress-induced obesity and the emotional nervous system. Trends Endocrinol Metab. 2010; 21:159-165. [PubMed: 19926299]

89. Chuang JC, Cui H, Mason BL, Mahgoub M, Bookout AL, Yu HG, et al. Chronic social defeat stress disrupts regulation of lipid synthesis. J Lipid Res. 2010; 51:1344-1353. [PubMed: 20129912]

90. Chuang JC, Krishnan V, Yu HG, Mason B, Cui H, Wilkinson MB, et al. A beta3-adrenergic-leptinmelanocortin circuit regulates behavioral and metabolic changes induced by chronic stress. Biol Psychiatry. 2010; 67:1075-1082. [PubMed: 20060958]

91. Pecoraro N, Reyes F, Gomez F, Bhargava A, Dallman MF. Chronic stress promotes palatable feeding, which reduces signs of stress: feedforward and feedback effects of chronic stress. Endocrinology. 2004; 145:3754-3762. [PubMed: 15142987]

92. Melhorn SJ, Krause EG, Scott KA, Mooney MR, Johnson JD, Woods SC, et al. Meal patterns and hypothalamic NPY expression during chronic social stress and recovery. Am J Physiol Regul Integr Comp Physiol. 299:R813-822. [PubMed: 20610828]

93. Pankevich DE, Teegarden SL, Hedin AD, Jensen CL, Bale TL. Caloric restriction experience reprograms stress and orexigenic pathways and promotes binge eating. J Neurosci. 2010; 30:16399-16407. [PubMed: 21123586]

94. Teegarden SL, Bale TL. Effects of stress on dietary preference and intake are dependent on access and stress sensitivity. Physiol Behav. 2008; 93:713-723. [PubMed: 18155095]

95. Finger BC, Dinan TG, Cryan JF. The temporal impact of chronic intermittent psychosocial stress on high-fat diet-induced alterations in body weight. Psychoneuroendocrinology. 2011

96. Finger BC, Dinan TG, Cryan JF. High-fat diet selectively protects against the effects of chronic social stress in the mouse. Neuroscience. 2011; 192:351-360. [PubMed: 21742017]

97. Leggio L. Role of the ghrelin system in alcoholism: Acting on the growth hormone secretagogue receptor to treat alcohol-related diseases. Drug News Perspect. 2010; 23:157-166. [PubMed: 20440417]

98. Dickson SL, Egecioglu E, Landgren S, Skibicka KP, Engel JA, Jerlhag E. The role of the central ghrelin system in reward from food and chemical drugs. Mol Cell Endocrinol. 2011; 340:80-87. [PubMed: 21354264] 
99. Skibicka KP, Dickson SL. Ghrelin and food reward: the story of potential underlying substrates. Peptides. 2011; 32:2265-2273. [PubMed: 21621573]

100. Jerlhag E. Systemic administration of ghrelin induces conditioned place preference and stimulates accumbal dopamine. Addict Biol. 2008; 13:358-363. [PubMed: 18782383] 


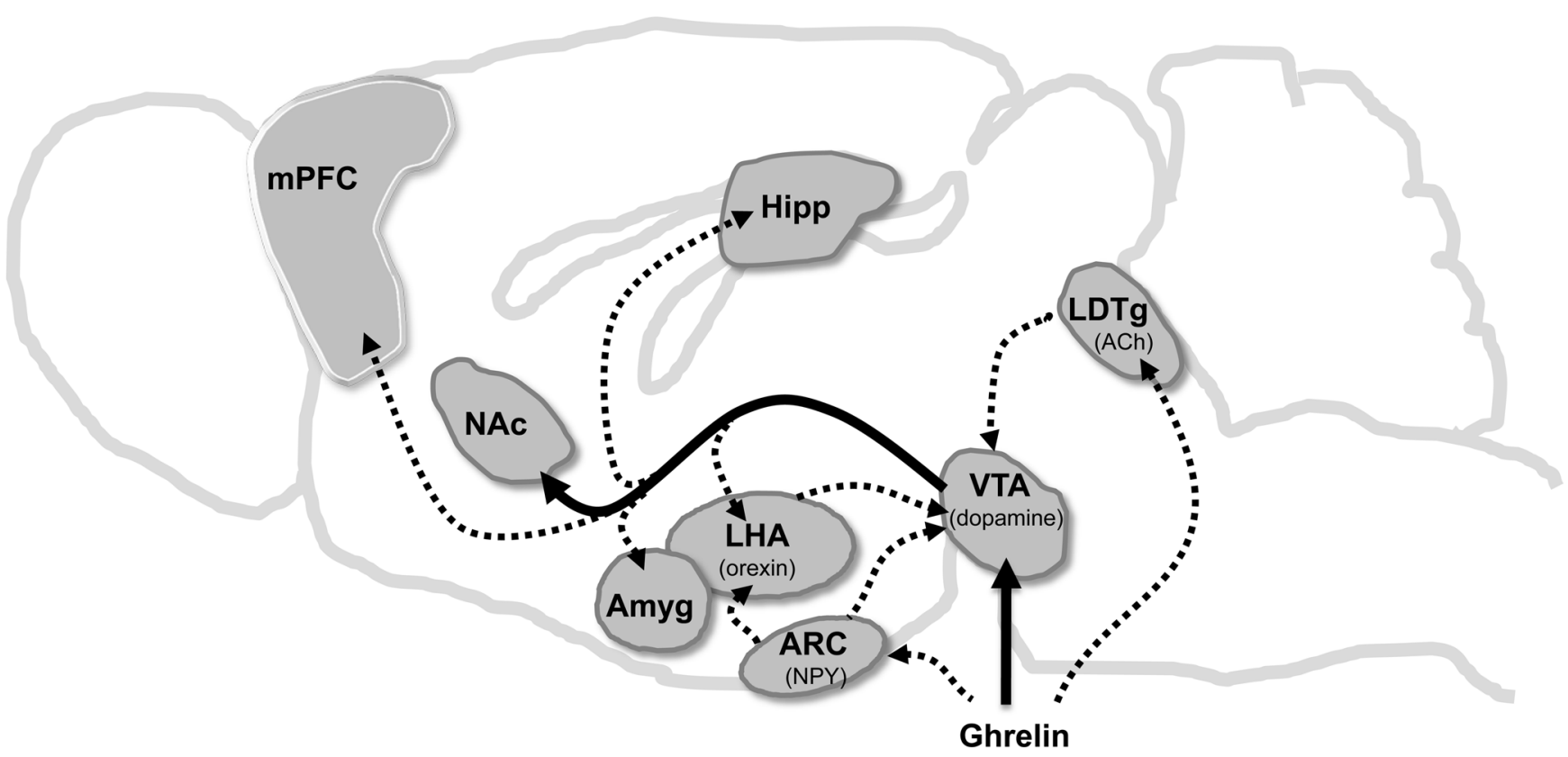

Figure 1. Model of ghrelin action on the mesolimbic reward circuitry in the rodent brain Depicted is a sagittal view of the rodent brain in which regions implicated in ghrelin's regulation of the rewarding value of food are highlighted. Signaling within dopaminegic neurons of the ventral tegmental area (VTA) mediate ghrelin's actions on food reward. Ghrelin induces overflow of dopamine within the nucleus accumbens (NAc). VTA neurons also send projections to the lateral hypothalamic area (LHA), amygdala (Amyg), hippocampus (Hipp) and medial prefrontal cortex (mPFC), although engagement of these brain regions by ghrelin acting via the VTA is currently unclear. A role for cholinergic (ACh) neurons emanating from the laterodorsal tegmental area (LDTg) in the regulation of this circuitry has also been proposed. Other signals, such as NPY, orexins, glutamate and endocannabinoids, have been shown to modulate ghrelin's action on food reward, although the anatomic locations of neurons producing these signals remain unclear. Solid lines and dotted lines represent established and hypothesized connections, respectively. 